\title{
Salt Stress and Homobrassinosteroid Interactions during Germination in Barley Roots
}

\author{
Sevgi MARAKLI*, Aslihan TEMEL, Nermin GOZUKIRMIZI \\ Istanbul University, Faculty of Science, Department of Molecular Biology and Genetics, 34134, Vezneciler Street-Istanbul, Turkey; \\ sevgi.marakli@istanbul.edu.tr ( ${ }^{*}$ correspondingauthor)
}

\begin{abstract}
Potential alleviation effects of Homobrassinosteroid (HBR) ( 0.5 and $1 \mu \mathrm{M} \mathrm{HBR}$ ) on root germination, cell division and antioxidant system enzymes (superoxide dismutase and catalase) of barley (Hordeum vulgare L. cv. 'Hilal') roots grown under different salt concentrations $(150 \mathrm{mM}$ and $250 \mathrm{mM}$ ) were investigated during 48 and $72 \mathrm{~h}$ at dark with their controls. Salt applications decreased primary root lengths, seminal root lengths, number of roots from one seed, mitotic activity and induced mitotic abnormalities. In addition, salt application decreased protein content but increased enzyme activities both at $48 \mathrm{~h}$ and $72 \mathrm{~h}$ when compared to control. Roots treated with HBR enhanced root lengths and root number. HBR-treated roots showed more mitotic activity, mitotic abnormalities and significant enlargements at the root tips when compared to controls and only salt-treated samples. Salt + HBR applications stimulated root lengths and showed more mitotic activity and mitotic abnormalities when compared to only salt-treated samples. Salt application increased superoxide dismutase and catalase activities both at $48 \mathrm{~h}$ and $72 \mathrm{~h}$. However, HBR application decreased total soluble protein content and increased enzyme activities especially at $48 \mathrm{~h}$ compared to control. Depending on concentration and timing, salt + HBR treatments showed varying results in total soluble protein content and enzyme activities. There was also a significant change in protein banding patterns of experimental groups separated by SDS-PAGE. These findings are expected to contribute to understanding of how HBR affect barley roots grown under different salt concentrations.
\end{abstract}

Keywords: abiotic stress, antioxidant enzyme activities, development of plant, mitotic index, plant hormone

\section{Introduction}

Salinity affects plant growth, activity of major cytosolic enzymes by disturbing intracellular potassium homeostasis, causing oxidative stress and programmed cell death, reduced nutrient uptake, metabolic toxicity, inhibition of photosynthesis, reduced $\mathrm{CO}_{2}$ assimilation and reduced root respiration (Sairam and Srivastava, 2002; Cuin and Shabala, 2007; Chen et al., 2007; Shabala, 2009; Abogadallah, 2010; Demirkiran et al., 2013; Liu et al., 2014).

Reactive Oxygen Species (ROS) are highly toxic and can greatly disrupt normal metabolism through membrane lipid peroxidation, DNA/RNA nicking, protein oxidation and enzyme inhibition (Tanou et al., 2009). Acclimation to salinity may be achieved via enhancing the antioxidant defence system (Saha et al., 2010). Plants have evolved a series of defence mechanisms to maintain the balance between the production of activated oxygen species and scavenging capacity of antioxidants. Plants possess a number of antioxidant enzymes like glutathione reductase (GR), peroxidase (POX), superoxide dismutase (SOD), guaiacol peroxidase (POD), catalase (CAT), ascorbate peroxidase and glutathione reductase for protection against the damaging effects of ROS (Bhaduri and Fulekar, 2012; Fariduddin et al., 2013).

Brassinosteroids (BRs) are a special class of plant polyhydroxysteroids that play essential roles during normal plant growth and development. They bind to a small family of leucine-rich repeat receptor kinases (BRI1) at the cell surface, thus initiating an intracellular signal transduction cascade that results in the altered expression of hundreds of genes which are implicated for diverse functions including increased adaptation to various abiotic stresses such as those induced by salts, drought, low and high temperature and heavy metals (Abdullahi et al., 2002; Sharma and Bhardwaj, 2007; Bajguz and Hayat, 2009; Farooq et al., 2009). Some researchers have suggested that brassinosteroids promote root elongation and mitosis in a wide range in low concentrations but not high concentrations ( $\mathrm{Hu}$ et al., 2000; Howell et al., 2007; Kartal et al., 2009).

Hordeum vulgare L. (barley) is an important cereal crop for both malting industry and animal husbandry. It is also an excellent model organism for research in biochemistry, physiology, genetics, molecular biology and genomics. The objective of the present study was to investigate the effects 
447

of exogenously applied 28-Homobrassinolide (HBR) on the alleviation of salt stresses on root germination, cell division and antioxidant system in barley seeds. For those purposes, barley seeds were grown under control (only water), only salt $(150 \mathrm{mM}$ and $250 \mathrm{mM})$, only $\operatorname{HBR}(0.5 \mu \mathrm{M}$ and $1 \mu \mathrm{M})$ and salt + HBR conditions for $48 \mathrm{~h}$ and $72 \mathrm{~h}$ at dark.

\section{Materials and methods}

\section{Plant material}

Seeds of Hordeum vulgare L. cv. 'Hilal' were used as plant material. Four different experiment groups were prepared at 48 $\mathrm{h}$ and $72 \mathrm{~h}$. The first group was control group. In the second group, sodium chloride $(\mathrm{NaCl})$ was used for generating salt stress (150 mM and $250 \mathrm{mM}$ ) on barley seeds. Only HBR (0.5 $\mu \mathrm{M}$ and $1 \mu \mathrm{M})$ was applied in the third group. In the last group, HBR $(0.5 \mu \mathrm{M}$ and $1 \mu \mathrm{M})$ was applied on barley seeds supplemented with $150 \mathrm{mM}$ and $250 \mathrm{mM}$ salt concentrations. Seeds were placed randomly in Petri dishes $(9 \mathrm{~cm}$ diameter) containing filter paper soaked in (a) only $\mathrm{H}_{2} \mathrm{O}$ (control), (b) $150 \mathrm{mM} \mathrm{NaCl}$, (c) $250 \mathrm{mM} \mathrm{NaCl}$, (d) $0.5 \mu \mathrm{L} \mathrm{HBR}$, (e) $1 \mu \mathrm{L}$ $\mathrm{HBR}$, (f) $150 \mathrm{mM} \mathrm{NaCl}+0.5 \mu \mathrm{M} \mathrm{HBR},(\mathrm{g}) 150 \mathrm{mM} \mathrm{NaCl}$ $+1 \mu \mathrm{M} \mathrm{HBR}$, (h) $250 \mathrm{mM} \mathrm{NaCl}+0.5 \mu \mathrm{M} \mathrm{HBR}$ and (i) 250 $\mathrm{mM} \mathrm{NaCl}+1 \mu \mathrm{M}$ HBR-supplemented distilled water. All cultures were kept at dark in a controlled growth chamber (26 $\left.{ }^{\circ} \mathrm{C}\right)$. Each concentration with three separate experiments was evaluated. Totally 135 barley seeds for $48 \mathrm{~h}$ and 135 barley seeds for $72 \mathrm{~h}$ were used ( 5 seeds in each petri dish, three replicates for 9 different applications). $1 \mathrm{mg}$ of HBR (H1267, Sigma) was dissolved in ethanol to yield a $10 \mathrm{mM}$ stock solution which used for the preparation of experiments.

\section{Growth measurements}

After $48 \mathrm{~h}$ and $72 \mathrm{~h}$, primary and seminal root lengths were measured. Root numbers from each seed were recorded. In addition, germination percent for each application was calculated.

\section{Cytological analyses}

The roots of controls, only salt treated, only HBR treated and salt + HBR treated seedlings were fixed in 1:3 acetoalcohol. The fixed root tips were hydrolysed in $1 \mathrm{M} \mathrm{HCl}$ at $60^{\circ} \mathrm{C}$ for $20 \mathrm{~min}$, stained with Feulgen for $1-1.5 \mathrm{~h}$, smashed in a drop of $45 \%$ acetic acid and squashed (Sharma and Gupta, 1982). In squash preparations, mitosis was investigated and mitotic index (\%) was calculated. About 1.000 cells were counted for each serial of treatments and control materials.

\section{Determination of protein content and antioxidant enzyme activities}

Controls and treated roots were first homogenized in a sterile mortar and pestle with liquid nitrogen, subsequently 1 $\mathrm{ml}$ extraction buffer (50 mM PBS [0.2 M monobasic sodium phosphate, $0.2 \mathrm{mM}$ dibasic sodium phosphate $\mathrm{pH}$ 7.0], 0.1 mM EDTA, 4\% polyvinylpyrrolidone) was used per $0.01 \mathrm{mg}$ plant material. The homogenate was centrifuged at $10.500 \mathrm{~g}$ for $20 \mathrm{~min}$ at $4^{\circ} \mathrm{C}$ (Pan et al., 2006). Supernatant was used for protein content and enzyme activity assays. Total soluble protein contents of the enzyme extracts were determined according to Bradford (1976) using bovine serum albumin (BSA) as a standard. Characterization of protein profiles was carried out using sodium dodecyl sulfate-polyacrylamide gel electrophoresis (SDS-PAGE). Supernatant for each concentration were denatured by heating at $100{ }^{\circ} \mathrm{C}$ for 5 minutes and loaded in $15 \%$ acrylamide slab gel containing $10 \%$ SDS. Run was performed at $16 \mathrm{~mA}$ for 30 minutes followed by $32 \mathrm{~mA}$ till the tracing bromophenol blue dye reached the gel bottom. Protein bands were visualized by staining the gels with 0.1\% Coomassie Brilliant Blue R-250.

SOD activity was determined by measuring the ability of enzyme extract to inhibit the photochemical reduction of nitroblue tetrazolium (NBT), as described by Cakmak and Marschner (1992), which measures inhibition of the photochemical reduction of nitroblue tetrazolium (NBT) spectrophotometrically at $560 \mathrm{~nm}$. One unit of activity was determined as amount of enzyme required to inhibit the photoreduction of NBT to blue formazan by $50 \%$ and was expressed as SOD unit's mg protein ${ }^{-1}$. The reaction mixture contained $50 \mathrm{mM}$ phosphate buffer ( $\mathrm{pH} 7.0), 0.1 \mathrm{mM} \mathrm{Na}$ EDTA, $50 \mathrm{mM} \mathrm{Na} \mathrm{CO}_{3}, 13 \mathrm{mM}$ L-methionine, $75 \mu \mathrm{M}$ pnitrobluetetrazolium chloride (NBT) and $2 \mu \mathrm{M}$ riboflavin. Reactions were carried out at $25^{\circ} \mathrm{C}$, under light intensity of about $300 \mathrm{umol}^{-1} \mathrm{~m}^{-1} \mathrm{~s}^{-1}$ through $10 \mathrm{~min}$.

Catalase activity was determined according to Cho et al. (2000), who measured the decline of the extinction of $\mathrm{H}_{2} \mathrm{O}_{2}$ at the maximum absorption at $240 \mathrm{~nm}$. About $5 \mu \mathrm{l}$ of samples were added to the reaction mixture containing $130.5 \mu \mathrm{l} \mathrm{H}_{2} \mathrm{O}$, $20 \mu \mathrm{l}$ phosphate buffer $(50 \mathrm{mM}, \mathrm{pH} 7.0)$ and $44.5 \mu l$ hydrogen peroxide (35\%). Spectrophotometric readings were obtained after addition of enzyme extract for 120 seconds of 10 second intervals and results were presented as $\Delta \mathrm{A}_{240} / \mathrm{min} / \mathrm{mg}$ protein.

\section{Statistical analysis}

All parameters were evaluated statistically by ANOVA with SPSS 16.0 program for studying the interaction of controls, only salt treated, only HBR treated and salt + HBR treated samples. Root lengths, number of roots from one seed and enzyme analyses were expressed as mean \pm SD of three independent replicates. For the statistical evaluation of the results, significance was accepted at the probability level $\mathrm{P}<0.05$ for root lengths (Tabs. $2-3$ ), $\mathrm{P}>0.1$ and $\mathrm{P}<$ 0.1 for enzyme analyses (Tab. 5 ).

\section{Results and discussions}

Barley seeds grown under control (only $\mathrm{H}_{2} \mathrm{O}$ ), salt stress (150 mM and $250 \mathrm{mM})$, HBR application $(0.5 \mu \mathrm{M}$ and $1 \mu \mathrm{M})$ and salt + HBR application showed different root lengths at 48 $\mathrm{h}$ and $72 \mathrm{~h}$ (Fig. 1 and 2, respectively). 0.5 and $1 \mu \mathrm{M}$ HBR

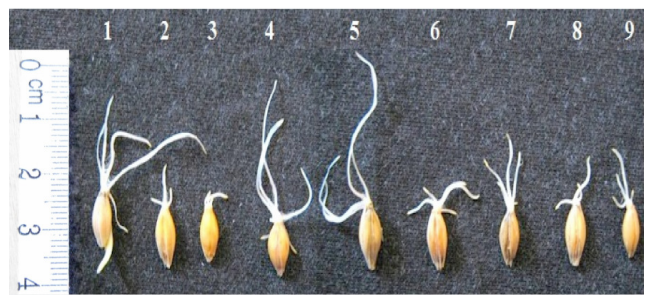

Fig. 1. Morphological view of Hordeum vulgare L. cv. 'Hilal' seeds germinated between filter papers at dark for $48 \mathrm{~h}$. Variants: $1=$ control; $2=150 \mathrm{mM} \mathrm{NaCl} ; 3=250 \mathrm{mM} \mathrm{NaCl} ; 4=0.5 \mu \mathrm{M} \mathrm{HBR}$; $5=1 \mu \mathrm{M} \mathrm{HBR} ; 6=150 \mathrm{mM} \mathrm{NaCl}+0.5 \mu \mathrm{M} \mathrm{HBR} ; 7=150 \mathrm{mM}$ $\mathrm{NaCl}+1 \mu \mathrm{M}$ HBR; $8=250 \mathrm{mM} \mathrm{NaCl}+0.5 \mu \mathrm{M}$ HBR; $9=250$ $\mathrm{mMNaCl}+1 \mu \mathrm{MHBR}$, respectively 
application alleviated the negative effects of salt on barley roots (6, 7, 8, 9 in Figs. 1-2).

Germination percentage of barley seeds were recorded.

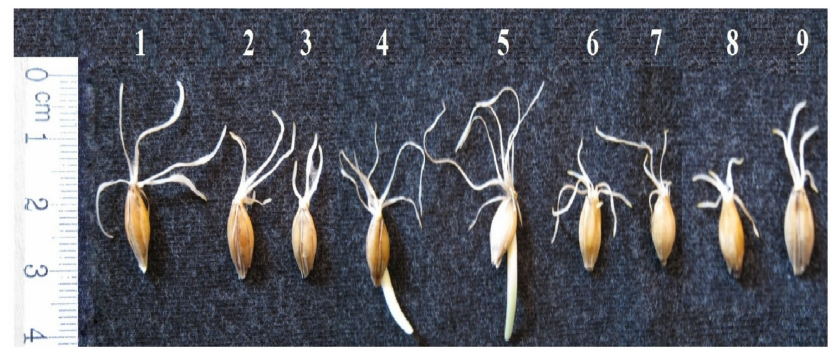

Fig. 2. Morphological view of Hordeum vulgare L. cv. 'Hilal' seeds germinated between filter papers at dark for $72 \mathrm{~h}$. Variants: $1=$ control; $2=150 \mathrm{mM} \mathrm{NaCl} ; 3=250 \mathrm{mM} \mathrm{NaCl}$; $4=0.5 \mu \mathrm{M}$ HBR; $5=1 \mu \mathrm{M}$ HBR; $6=150 \mathrm{mM} \mathrm{NaCl}+0.5$ $\mu \mathrm{M} \mathrm{HBR} ; 7=150 \mathrm{mM} \mathrm{NaCl}+1 \mu \mathrm{M}$ HBR; $8=250 \mathrm{mM}$ $\mathrm{NaCl}+0.5 \mu \mathrm{M}$ HBR; $9=250 \mathrm{mM} \mathrm{NaCl}+1 \mu \mathrm{M}$ HBR, respectively

Germination percentage of barley seeds which were treated with salt, HBR and salt + HBR showed different results at $48 \mathrm{~h}$ and $72 \mathrm{~h}$. Salt application decreased germination while HBR increased. High HBR concentration showed better results to alleviate salt stress on barley seeds (Tab. 1).

Increased salt concentration caused negative effect on primary root and seminal root lengths. As compared to control $(1.8 \pm 0.6$ and $2.4 \pm 0.4,48 \mathrm{~h}$ and $72 \mathrm{~h}$, respectively), the lengths of primary root decreased in $150 \mathrm{mM}$ salt concentration $(1 \pm 0.4$ and $1.5 \pm 0.6,48 \mathrm{~h}$ and $72 \mathrm{~h}$, respectively $)$ and $250 \mathrm{mM}(0.5 \pm 0.2$ and $0.9 \pm 0.2,48 \mathrm{~h}$ and 72 $h$, respectively) salt concentration (Tabs. 2-3). The same result could also be seen on seminal root lengths and number of roots from one seed. On the other hand, only HBR applications ( 0.5 $\mu \mathrm{M}$ and $1 \mu \mathrm{M}$ ) increased all 3 parameters on barley seeds. HBR was applied on same petri dishes which were supplemented with different salt concentrations to alleviate the negative effect of salt stress on barley seeds. As a result, HBR application increased primary root lengths in $150 \mathrm{mM}$ and $250 \mathrm{mM}$ salt concentration especially at $48 \mathrm{~h}$.

The hormone increased seminal root lengths in $150 \mathrm{mM}$ salt but there was no significant change on seminal root lengths in $250 \mathrm{mM}$ salt concentration at $48 \mathrm{~h}$. In addition, number of emerging roots per seed in $150 \mathrm{mM} \mathrm{NaCl}$ treatment was increased with $0.5 \mu \mathrm{M}$ and $1 \mu \mathrm{M}$ HBR application (Tab. 2). At $72 \mathrm{~h}$, primary root lengths were increased in both $150 \mathrm{mM}$ and $250 \mathrm{mM}$ salt concentrations. There was no significant change

Tab. 1. Effect of salt, HBR and salt + HBR applications on germination of barley seeds (\%)

\begin{tabular}{ccc} 
Hordeum vulgare L. cv. & \multicolumn{2}{c}{ Germination (\%) } \\
\cline { 2 - 3 } 'Hilal' (Treatment variants) & $48 \mathrm{~h}$ & $72 \mathrm{~h}$ \\
\hline Control & 100 & 93 \\
$150 \mathrm{mM}$ salt concentration & 87 & 93 \\
$250 \mathrm{mM}$ salt concentration & 67 & 67 \\
$0.5 \mu \mathrm{M}$ HBR & 93 & 93 \\
$1 \mu \mathrm{M}$ HBR & 87 & 93 \\
$150 \mathrm{mM}$ salt $+0.5 \mu \mathrm{M}$ HBR & 100 & 93 \\
$150 \mathrm{mM}$ salt $+1 \mu \mathrm{M}$ HBR & 93 & 100 \\
$250 \mathrm{mM}$ salt $+0.5 \mu \mathrm{M}$ HBR & 80 & 80 \\
$250 \mathrm{mM}$ salt $+1 \mu \mathrm{M}$ HBR & 73 & 93 \\
\hline
\end{tabular}

on seminal root lengths in 150 and $250 \mathrm{mM}$ salt concentrations. On the other hand, root number was increased in both concentrations (Tab. 3).

Salt application decreased primary root lengths $(44.4 \%$ and $72 \%, 150 \mathrm{mM}$ salt and $250 \mathrm{mM}$ salt respectively at $48 \mathrm{~h} ; 37.5 \%$ and $62.5 \% 150 \mathrm{mM}$ salt and $250 \mathrm{mM}$ salt respectively at $72 \mathrm{~h}$ ), seminal root lengths $(50 \%$ and $75 \%, 150 \mathrm{mM}$ salt and 250 $\mathrm{mM}$ salt respectively at $48 \mathrm{~h} ; 31.3 \%$ and $62.5 \% 150 \mathrm{mM}$ salt and $250 \mathrm{mM}$ salt respectively at $72 \mathrm{~h}$ ) and number of roots from one seed $(25 \%$ and $50 \%, 150 \mathrm{mM}$ salt and $250 \mathrm{mM}$ salt respectively at $48 \mathrm{~h} ; 16 \%$ and $32 \% 150 \mathrm{mM}$ salt and $250 \mathrm{mM}$ salt respectively at $72 \mathrm{~h}$ ) as compared to control. HBR (0.5-1 $\mu \mathrm{M}$ HBR) applications enhanced primary root lengths (22\% and $38.9 \%, 0.5 \mu \mathrm{M}$ HBR and $1 \mu \mathrm{M}$ HBR respectively at $48 \mathrm{~h}$; $12.5 \%$ and $8.3 \% 0.5 \mu \mathrm{M}$ HBR and $1 \mu \mathrm{M}$ HBR respectively at $72 \mathrm{~h}$ ), seminal root lengths ( $17 \%$ and $33 \%, 0.5 \mu \mathrm{M} \mathrm{HBR}$ and 1 $\mu \mathrm{M}$ HBR respectively at $48 \mathrm{~h} ; 6.25 \%$ in $0.5 \mu \mathrm{M}$ HBR at $72 \mathrm{~h}$ ) and number of roots from one seed $(7 \%$ and $1.8 \%, 0.5 \mu \mathrm{M}$ HBR and $1 \mu \mathrm{M}$ HBR, respectively at $48 \mathrm{~h} ; 1.6 \%$ and $6 \%, 0.5$ $\mu \mathrm{M}$ HBR and $1 \mu \mathrm{M}$ HBR respectively at $72 \mathrm{~h}$ ) as compared to control at $48 \mathrm{~h}$ and $72 \mathrm{~h}$.

Salt + HBR applications altered primary root lengths, seminal root lengths and number of roots from one seed as compared to only salt applications at $48 \mathrm{~h}$ and $72 \mathrm{~h}$. Salt decreased but salt + HBR application enhanced primary root

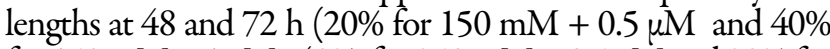
for $150 \mathrm{mM}+1 \mu \mathrm{M} ; 40 \%$ for $250 \mathrm{mM}+0.5 \mu \mathrm{M}$ and $20 \%$ for $250 \mathrm{mM}+1 \mu \mathrm{M}$ at $48 \mathrm{~h}$ ). It could be said that high HBR concentration had positive effect on low salt stress. This differences altered at $72 \mathrm{~h}(13.3 \%$ for $150 \mathrm{mM}+0.5 \mu \mathrm{M}$ and $6.7 \%$ for $150 \mathrm{mM}+1 \mu \mathrm{M} ; 11 \%$ for $250 \mathrm{mM}+0.5 \mu \mathrm{M}$ and $11 \%$ for $250 \mathrm{mM}+1 \mu \mathrm{M})$. The same result was observed in seminal root lengths and root numbers at $48 \mathrm{~h}$ and $72 \mathrm{~h}$.

\section{Cytological analyses}

Mitotic index in controls, only salt, only HBR and salt + HBR-treated barley seeds were shown in Tab. 4. Control barley roots had $20.4 \%$ and $23.6 \%$ ( $48 \mathrm{~h}$ and $72 \mathrm{~h}$, respectively) of the cells in various stages of mitosis. Salt stress reduced mitotic index $(8.3 \%$ and $5.6 \%$ in $150 \mathrm{mM}$ salt treated and $5.5 \%$ and $3.6 \%$ in $250 \mathrm{mM}$ salt treated samples for $48 \mathrm{~h}$ and $72 \mathrm{~h}$ ). Moreover, mitotic index of only HBR application was higher than both control and salt treated samples. Increasing concentration of HBR alleviated salt stress effectively but their effect could be seen after long time ( $1 \mu \mathrm{M}$ application showed more mitotic index for $150 \mathrm{mM}$ salt and $250 \mathrm{mM}$ salt application both at $48 \mathrm{~h}$ and $72 \mathrm{~h}$ ). Mitotic abnormalities such as vacuole in cells, disorganized prophase, interphase and prophase in the same cells, disorganized metaphase, anaphase bridge, disorganized anaphase could be seen in only salt treated, only HBR treated and salt + HBR treated samples.

\section{Determination of protein content and antioxidant enzyme activities}

Total proteins were extracted from experimental groups after $48 \mathrm{~h}$ and $72 \mathrm{~h}$ treatment and analysed by SDS-PAGE. As visualized from SDS-PAGE, the intensity of several protein bands of molecular weight $20 \mathrm{kDa}$ decreased as a result of salt, HBR and salt + HBR treatment at $48 \mathrm{~h}$. HBR and salt also cause a significant change in the electrophoretic profiles of experimental groups separated by SDS-PAGE during $48 \mathrm{~h}$ (Fig. 3). 
449

Protein content of all samples was increased at $72 \mathrm{~h}$. High HBR application showed positive effect on low salt stress (5.7 $\pm 1.94,6.48 \pm 1.74,48 \mathrm{~h}$ and $72 \mathrm{~h}$, respectively). Protein content of $250 \mathrm{mM}$ salt $+0.5 \mu \mathrm{M}$ HBR in $72 \mathrm{~h}(6.71 \pm 2)$ was higher than protein content of $250 \mathrm{mM}$ salt $+1 \mu \mathrm{M}$ HBR in $48 \mathrm{~h}(5.23 \pm 3)$. This result showed that HBR application stimulated reverse effect on high salt stress during long period of time (Tab. 5).
Only salt application and only HBR application enhanced enzyme activities as compared to control. Activity of SOD in high salt treatment was reduced by high $\mathrm{HBR}$ concentration $(0.2 \pm 0.2$ for 48 h, $0.29 \pm 0.35$ for 72 h). High HBR application decreased catalase activity in $150 \mathrm{mM}$ salt $+1 \mu \mathrm{M}$ HBR in $72 \mathrm{~h}(0.02 \pm 0.01)$. Activities of SOD and catalase enzymes were dependent on the concentration of salt and $\operatorname{HBR}($ Tab. 5).

Tab. 2. Lengths and roots number of Hordeum vulgare L. cv. 'Hilal' after $48 \mathrm{~h}$ germination between filter papers at dark

\begin{tabular}{|c|c|c|c|c|c|c|c|c|c|}
\hline Trait & Control & $\begin{array}{l}150 \mathrm{mM} \\
\text { salt }\end{array}$ & $\begin{array}{l}250 \mathrm{mM} \\
\text { salt }\end{array}$ & $\begin{array}{c}0.5 \mu \mathrm{M} \\
\text { HBR }\end{array}$ & $1 \mu \mathrm{M} \mathrm{HBR}$ & $\begin{array}{c}150 \mathrm{mM} \\
\text { salt }+0.5 \mu \\
\text { M HBR }\end{array}$ & $\begin{array}{c}150 \mathrm{mM} \\
\text { salt }+1 \mu \mathrm{M} \\
\text { HBR }\end{array}$ & $\begin{array}{c}250 \mathrm{mM} \\
\text { salt }+0.5 \mu \\
\text { M HBR }\end{array}$ & $\begin{array}{c}250 \mathrm{mM} \\
\text { salt }+1 \mu \mathrm{M} \\
\text { HBR }\end{array}$ \\
\hline $\begin{array}{l}\text { Average length of } \\
\text { primary roots }(\mathrm{cm})\end{array}$ & $1.8 \pm 0.6$ & $1 \pm 0.4$ & $0.5 \pm 0.2$ & $2.2 \pm 0.2$ & $2.5 \pm 0.4$ & $1.2 \pm 0.4$ & $1.4 \pm 0.3$ & $0.7 \pm 0.3$ & $0.6 \pm 0.3$ \\
\hline $\begin{array}{l}\text { Average length of } \\
\text { seminal roots }(\mathrm{cm})\end{array}$ & $1.2 \pm 0.5$ & $0.6 \pm 0.3$ & $0.3 \pm 0.2$ & $1,4 \pm 0.6$ & $1.6 \pm 0.6$ & $0.7 \pm 0.4$ & $0,8 \pm 0.3$ & $0,3 \pm 0.2$ & $0,3 \pm 0.2$ \\
\hline $\begin{array}{l}\text { Number of roots } \\
\text { from one seed }\end{array}$ & $5.6 \pm 0.6$ & $4.2 \pm 0.4$ & $2.8 \pm 1,5$ & $6 \pm 0.7$ & $5.7 \pm 0.7$ & $4.4 \pm 1.1$ & $5 \pm 0.7$ & $2.7 \pm 1.2$ & $2.5 \pm 1.4$ \\
\hline
\end{tabular}

Values are mean \pm SD based on three replicates, $\mathrm{P}<0.05$

Tab. 3. Lengths and roots number of Hordeum vulgare L. cv. 'Hilal' after $72 \mathrm{~h}$ germination between filter papers at dark

\begin{tabular}{|c|c|c|c|c|c|c|c|c|c|}
\hline Trait & Control & $\begin{array}{l}150 \mathrm{mM} \\
\text { salt }\end{array}$ & $\begin{array}{l}250 \mathrm{mM} \\
\text { salt }\end{array}$ & $\begin{array}{c}0.5 \mu \mathrm{M} \\
\mathrm{HBR}\end{array}$ & $1 \mu \mathrm{M} \mathrm{HBR}$ & $\begin{array}{c}150 \mathrm{mM} \\
\text { salt }+0.5 \mu \\
\text { M HBR }\end{array}$ & $\begin{array}{c}150 \mathrm{mM} \\
\text { salt }+1 \mu \mathrm{M} \\
\text { HBR }\end{array}$ & $\begin{array}{c}250 \mathrm{mM} \\
\text { salt }+0.5 \mu \\
\mathrm{M} \mathrm{HBR}\end{array}$ & $\begin{array}{c}250 \mathrm{mM} \\
\text { salt }+1 \mu \mathrm{M} \\
\text { HBR }\end{array}$ \\
\hline $\begin{array}{l}\text { Average length of } \\
\text { primary roots }(\mathrm{cm})\end{array}$ & $2.4 \pm 0.4$ & $1.5 \pm 0.6$ & $0.9 \pm 0.2$ & $2.7 \pm 0.5$ & $2.6 \pm 0.4$ & $1.7 \pm 0.4$ & $1.6 \pm 0.3$ & $1 \pm 0.2$ & $1 \pm 0.2$ \\
\hline $\begin{array}{l}\text { Average length of } \\
\text { seminal roots }(\mathrm{cm})\end{array}$ & $1.6 \pm 0.6$ & $1.1 \pm 0.5$ & $0.6 \pm 0.2$ & $1.7 \pm 0.7$ & $1.6 \pm 0.6$ & $1 \pm 0.4$ & $1 \pm 0.4$ & $0.5 \pm 0.2$ & $0,6 \pm 0.2$ \\
\hline $\begin{array}{l}\text { Number of roots } \\
\text { from one seed }\end{array}$ & $6.3 \pm 0.5$ & $5.3 \pm 1.6$ & $4.3 \pm 1.2$ & $6.4 \pm 0.8$ & $6.7 \pm 0.7$ & $5.5 \pm 1$ & $5.4 \pm 0.7$ & $4.6 \pm 1$ & $4.5 \pm 0.8$ \\
\hline
\end{tabular}

Values are mean \pm SD based on three replicates, $\mathrm{P}<0.05$

Tab. 4. Mitotic index (1.000 cells counted) in Hordeum vulgare L. cv. 'Hilal' after $48 \mathrm{~h}$ and $72 \mathrm{~h}$ of germination

\begin{tabular}{|c|c|c|c|c|c|c|c|c|c|}
\hline Mitotic index (cells/time) & Control & $\begin{array}{l}150 \mathrm{mM} \\
\text { salt }\end{array}$ & $\begin{array}{c}250 \mathrm{mM} \\
\text { salt }\end{array}$ & $\begin{array}{c}0.5 \mu \mathrm{M} \\
\mathrm{HBR}\end{array}$ & $\begin{array}{l}1 \mu \mathrm{M} \\
\mathrm{HBR}\end{array}$ & $\begin{array}{c}150 \mathrm{mM} \\
\text { salt }+0.5 \mu \\
\text { M HBR }\end{array}$ & $\begin{array}{c}150 \mathrm{mM} \\
\text { salt }+1 \mu \mathrm{M} \\
\mathrm{HBR}\end{array}$ & $\begin{array}{c}250 \mathrm{mM} \\
\text { salt }+0.5 \mu \\
\text { M HBR }\end{array}$ & $\begin{array}{c}250 \mathrm{mM} \\
\text { salt }+1 \mu \mathrm{M} \\
\text { HBR }\end{array}$ \\
\hline Mitotic index (\%) (48 h) & 20.4 & 8.3 & 5.5 & 25.9 & 20.1 & 13.8 & 18.6 & 16.8 & 20.1 \\
\hline Mitotic index (\%) (72 h) & 23.6 & 5.6 & 3.6 & 23 & 24.1 & 14.3 & 21.9 & 10.4 & 22.2 \\
\hline
\end{tabular}

Tab. 5. Protein contents and antioxidant enzyme activities of Hordeum vulgare L. cv. 'Hilal' roots after 48 hours and 72 hours of germination between filter papers at dark in salt, HBR and salt + HBR application

\begin{tabular}{|c|c|c|c|c|c|c|c|c|c|}
\hline $\begin{array}{c}\text { Content/ } \\
\text { Activity }\end{array}$ & Control & $\begin{array}{c}150 \mathrm{mM} \\
\text { salt }\end{array}$ & $\begin{array}{l}250 \mathrm{mM} \\
\text { salt }\end{array}$ & $\begin{array}{c}0.5 \mu \mathrm{M} \\
\mathrm{HBR}\end{array}$ & $1 \mu \mathrm{M}$ HBR & $\begin{array}{c}150 \mathrm{mM} \\
\text { salt }+0.5 \mu \mathrm{M} \\
\text { HBR }\end{array}$ & $\begin{array}{c}150 \mathrm{mM} \\
\text { salt }+1 \mu \mathrm{M} \\
\text { HBR }\end{array}$ & $\begin{array}{c}250 \mathrm{mM} \\
\text { salt }+0.5 \mu \mathrm{M} \\
\text { HBR }\end{array}$ & $\begin{array}{c}250 \mathrm{mM} \\
\text { salt+1 } \mu \mathrm{M} \\
\text { HBR }\end{array}$ \\
\hline $\begin{array}{l}{ }^{*} \text { Protein } \\
\text { content } \mathrm{mg} / \mathrm{ml} \\
(48 \mathrm{~h})\end{array}$ & $5.9 \pm 2.75$ & $5.02 \pm 2.32$ & $4.4 \pm 2.86$ & $4.22 \pm 2.3$ & $3.55 \pm 0.7$ & $5.4 \pm 2.5$ & $5.7 \pm 1.94$ & $4.6 \pm 3$ & $5.23 \pm 3$ \\
\hline $\begin{array}{l}{ }^{*} \text { Protein } \\
\text { content } \mathrm{mg} / \mathrm{ml} \\
(72 \mathrm{~h})\end{array}$ & $6.1 \pm 1.77$ & $5.65 \pm 1.33$ & $6.1 \pm 1.78$ & $4.86 \pm 2.27$ & $5.5 \pm 1.15$ & $5.5 \pm 1.54$ & $6.48 \pm 1.74$ & $6.71 \pm 2$ & $5.6 \pm 2.29$ \\
\hline $\begin{array}{l}{ }^{*} \text { Superoxide } \\
\text { dismutase } \\
\text { activity } \\
\Delta \mathrm{A}_{560} / \mathrm{min} / \mathrm{mg} \\
\text { protein }(48 \mathrm{~h})\end{array}$ & $0.11 \pm 0.09$ & $0.21 \pm 0.22$ & $0.32 \pm 0.41$ & $0.23 \pm 0.3$ & $0.17 \pm 0.17$ & $0.18 \pm 0.18$ & $0.3 \pm 0.3$ & $0.3 \pm 0.3$ & $0.2 \pm 0.2$ \\
\hline $\begin{array}{l}{ }^{*} \text { Superoxide } \\
\text { dismutase } \\
\text { activity } \\
\Delta \mathrm{A}_{560} / \mathrm{min} / \mathrm{mg} \\
\text { protein }(72 \mathrm{~h})\end{array}$ & $0.27 \pm 0.38$ & $0.33 \pm 0.43$ & $0.34 \pm 0.36$ & $0.3 \pm 0.3$ & $0.95 \pm 1.43$ & $0.42 \pm 0.32$ & $0.35 \pm 0.38$ & $0.33 \pm 0.35$ & $0.29 \pm 0.35$ \\
\hline $\begin{array}{l}{ }^{* *} \text { Catalase } \\
\text { activity } \\
\Delta \mathrm{A}_{240} / \mathrm{min} / \mathrm{mg} \\
\text { protein }(48 \mathrm{~h})\end{array}$ & $0.06 \pm 0.07$ & $0.07 \pm 0.06$ & $0.1 \pm 0.1$ & $0.07 \pm 0.02$ & $0.13 \pm 0.14$ & $0.18 \pm 0.3$ & $0.08 \pm 0.03$ & $0.56 \pm 0.87$ & $0.06 \pm 0.04$ \\
\hline $\begin{array}{l}{ }^{*} \text { Catalase } \\
\text { activity } \\
\Delta \mathrm{A}_{240} / \mathrm{min} / \mathrm{mg} \\
\text { protein }(72 \mathrm{~h})\end{array}$ & $0.04 \pm 0.02$ & $0.05 \pm 0.04$ & $0.04 \pm 0.03$ & $0.04 \pm 0.03$ & $0.03 \pm 0.03$ & $0.04 \pm 0.01$ & $0.02 \pm 0.01$ & $0.05 \pm 0.04$ & $0.13 \pm 0.04$ \\
\hline
\end{tabular}




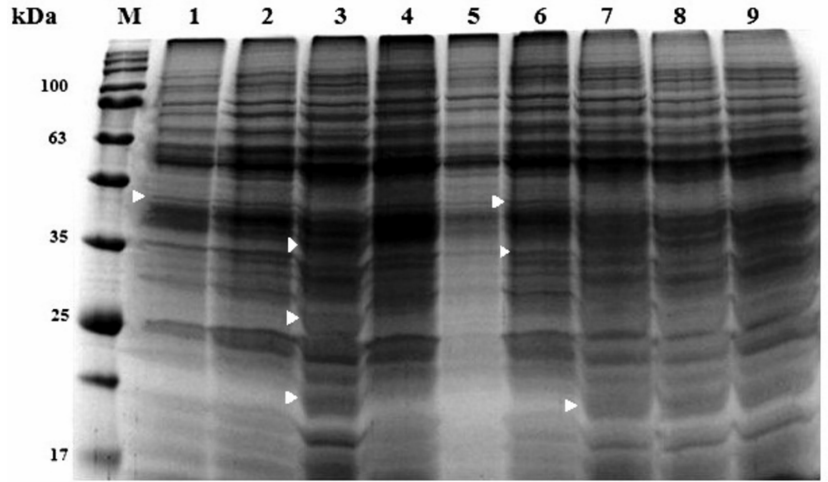

Fig. 3. Protein banding patterns of barley (Hordeum vulgare $\mathrm{L}$. cv. 'Hilal') seeds separated by SDS-PAGE at $48 \mathrm{~h}$. Variants: M = marker; 1 = control; $2=150 \mathrm{mM} \mathrm{NaCl} ; 3=250 \mathrm{mM} \mathrm{NaCl}$; $4=0.5 \mu \mathrm{M}$ HBR; $5=1 \mu \mathrm{M} \mathrm{HBR} ; 6=150 \mathrm{mM} \mathrm{NaCl}+0.5$ $\mu \mathrm{M}$ HBR; $7=150 \mathrm{mM} \mathrm{NaCl}+1 \mu \mathrm{M} \mathrm{HBR} ; 8=250 \mathrm{mM}$ $\mathrm{NaCl}+0.5 \mu \mathrm{M} \mathrm{HBR} ; 9=250 \mathrm{mM} \mathrm{NaCl}+1 \mu \mathrm{M} \mathrm{HBR}$, respectively (arrows indicate polymorphic bands)

\section{Discussion}

The present study indicates the alleviation effects of $\mathrm{HBR}$ $(0.5 \mu \mathrm{M}$ and $1 \mu \mathrm{M})$ on root germination, cell division, protein content and antioxidant system enzymes (superoxide dismutase and catalase) of barley (Hordeum vulgare L. cv. 'Hilal') grown under different salt concentrations $(150 \mathrm{mM}$ and $250 \mathrm{mM}$ ) in 48 and $72 \mathrm{~h}$. Increasing salt stress reduced root lengths, number of roots from one seed, germination percentage, mitotic activity and protein content, causing chromosomal aberrations and increased enzymatic activity when compared to controls. Only HBR application depending on the concentration and timing stimulated root lengths, number of roots from one seed and mitotic activity, decreased germination percentage, protein content and increased enzymatic activities compared to controls. When all parameters were examined, we observed HBR application on barley seeds under the salt stress alleviated the salt stress on barley seeds.

It was observed that salt stress reduced root elongation on barley and HBR application alleviated salt stress. These results are concordant with Dash and Panda (2001) who studied on Phaseolus mungo seeds. They concluded that a decrease in germination percentage, root length, shoot length, and fresh mass were observed with an increase in $\mathrm{NaCl}$ concentration (1\%,2\% and 3\%). Demirkiran et al. (2013) observed $50 \mathrm{mM}$ and $100 \mathrm{mM}$ salt concentration inhibited shoot growth, decreased fresh weight and protein content and increased SOD activity in a dose-dependent manner. In another study, rice seeds soaked in water or $150 \mathrm{mM} \mathrm{NaCl}$ in the presence or absence of $\mathrm{BR}$ were tested for germination and seed growth. When the salt solution was supplemented with $\mathrm{BR}$, the inhibitory effect of salt on germination was reduced considerably. The promotion of growth by $\mathrm{BR}$ under salt stress conditions was associated with enhanced levels of nucleic acids and soluble proteins (Anuradha and Rao, 2001). However, some studies provided conflicting results. Ozdemir et al. (2004) studied with 24-epibrassinolide effects on salt- sensitive rice cultivar IR-28 grown under salt stress. They reported that 24-epiBL caused inhibition of root elongation and curvature of rice seedlings under both control and salt stress conditions. This result was also previously reported for Arabidopsis (Clouse et al., 1993) and tomato (Dhaubhadel et al., 1999). Effects of BR could depend on concentration, timing and plant parts (Houimli et al., 2010). Liu et al. (2014) studied the effects of 24-epibrassinolide $\left(10^{-6}, 10^{-8}, 10\right.$ $\left.{ }^{10}, 10^{-12} \mathrm{M}\right)$ on salt-stressed canola. They found growth promoting effects of 24-epiBL on salt-stressed shoots and roots but $10^{-10} \mathrm{M}$ 24-epiBL inhibited root growth under control conditions. There are many reports showing that BRs could ameliorate plant growth under saline conditions in wheat, maize and pea (Shahbaz et al., 2008; El-Khallal et al., 2009; Shahid et al., 2011).

Results indicated that mitotic index decreased with increasing salt concentration. However, it increased with only HBR application as compared to control. Moreover, salt + HBR application also enhanced mitotic index when compared to only salt-treated samples. Hormone application depended on mostly concentration. Howell et al. (2007) reported the first detailed report about the effects of 24 epibrassinolide (BL) on chromosomes and the cell cycle. They investigated the effects on the mitotic index and the growth of onion (Allium cepa) root tips. They concluded that different doses of BL show dissimilar results. Increasing doses of BL (0.005 ppm, $0.05 \mathrm{ppm}$ and $0.5 \mathrm{ppm})$ demonstrated opposite effect on root tips as compared to controls. Low doses of $\mathrm{BL}(0.005 \mathrm{ppm})$ nearly doubled the mean root length and the number of mitosis over that of controls but differences were not statistically significant. Chromosomal aberrations were also seen in all samples except controls.

These results are supported by Tabur and Demir (2009). They studied on barley (Hordeum vulgare L. cv. 'Bulbul 89') and reported that plants grown on media containing 0.30 , 0.35 and $0.40 \mathrm{M} \mathrm{NaCl}$ showed a significant decrease in mitotic index and higher number of chromosomal abnormalities as compared to control. On the contrary of our results, they observed the mitotic index decreased $50 \%$ approximately in 24-epibrassinolide treated samples. In another study, Tabur and Demir (2010) used 0.30, 0.35, 0.40 and 0.45 molal salt concentrations and observed that the inhibitory effect of salt stress on mitotic index of barley (Hordeum vulgare L. cv. 'Bulbul 89') and chromosomal aberrations enhanced with increasing salt concentration. There are also different studies about BR effects on mitosis (Miyazawa et al., 2003; Aydin et al., 2006; Sondhi et al., 2008; Kartal et al., 2009).

We also observed that only HBR decreased protein content as compared to control but salt + HBR application enhanced protein content in only salt treated samples. Bajguz (2000) reported different results. In their study, protein levels of Chlorella vulgaris increased, after BR application. Ozdemir et al. (2004) also concluded that exogenous application of 24epiBL significantly increased soluble protein content of rice seedlings in both 24-epiBL and 24-epiBL $+\mathrm{NaCl}$ treated groups compared with the control group. In addition, Kartal et al. (2009) concluded that HBR stimulated total soluble protein content in treated materials with $0.1 \mu \mathrm{M}$ and $0.5 \mu \mathrm{M}$ HBR compared to control. Differences in results might have 
451

originated from experimental materials, duration and doses of HBR hormone. Protein banding patterns of our experimental groups were also different. Parida et al. (2004) studied two-month-old seedlings of Bruguiera parvifora treated with varying levels of $\mathrm{NaCl}(100,200$ and $400 \mathrm{mM})$. As a result of SDS-PAGE analysis, they concluded that the intensity of several protein bands of molecular decreased as a result of $\mathrm{NaCl}$ treatment.

Enzyme activity of only salt-treated and only HBRtreated samples was enhanced compared with controls. On the contrary, salt + HBR treated samples indicated different results depending on concentrations and duration. Supporting our data, Agami (2013) studied maize and concluded that activities of antioxidant enzymes (peroxidase and catalase) in maize plants were decreased under salt stress while increased after salicylic acid (SA) or 24-epibrassinolide (EBL) application.

In another study, Talaat and Shawky (2013) stated that two wheat (Triticum aestivum L.) cultivars, Sids 1 and Giza 168 , were grown under non-saline or saline conditions (4.7 and $9.4 \mathrm{dS} \mathrm{m}^{-1}$ ) and were sprayed with $0.00,0.05$ and $0.10 \mathrm{mg}$ $1^{-1}$ 24-epibrassinolide (EBL). Antioxidative enzyme activities (POX, CAT, SOD and GR) and antioxidative molecule contents (GSH and AsA) were considerably elevated by salt stress and/or EBL treatments. In literature, there are many studies which investigate the effects of BRs mainly focusing on plant growth and antioxidant systems (Anuradha and Rao, 2001; Nunez et al., 2003; Ozdemir et al., 2004; Ali et al., 2008; Arora et al., 2008; Rady, 2011; Choudhary et al., 2012). Different results from different studies could be arised from type of plants or HBR and salt concentrations and application types.

\section{Conclusion}

Data presented here is one of the first detailed analyses of alleviation effects of HBR on salt stressed barley root germination. Related to concentrations and duration, HBR improved growth parameters, mitotic index, chromosomal abnormalities and increased or decreased the level of antioxidant enzymes (superoxide dismutase and catalase) under stress and stress-free conditions. Salt stress effect barley growth and development. Our results are expected to contribute to find out alleviation of salt stress. Gene expression studies will provide inputs toward understanding how exogenous application of HBR alleviates saline stress responses at molecular level in barley.

\section{Acknowledgments}

This report is a part of $\mathrm{PhD}$ Thesis of Sevgi MARAKLI, Research Assistant in Biology Department, Amasya University. This study was supported by the Research Foundation of Istanbul University, Project No: 39465 and 39824.

\section{References}

Abdullahi BA, Gu XG, Gan QL, Yang YH (2002). Brassinolide amelioration of aluminum toxicity in mungbean seedling growth. J Plant Nutr 26(9):1725-1734.
Abogadallah GM (2010). Antioxidative defense under salt stress. Plant Signaling and Behavior 5(4):369-374.

Agami RA (2013). Alleviating the adverse effects of $\mathrm{NaCl}$ stress in maize seedlings by pretreating seeds with salicylic acid and 24-epibrassinolide. S Afr J Bot 88:171-177.

Ali Q, Athar HR, Ashraf M (2008). Modulation of growth, photosynthetic capacity and water relations in salt stressed wheat plants by exogenously applied 24epibrassinolide. Plant Growth Regul 56(2):107-116.

Anuradha S, Ram Rao SS (2001). Effect of brassinosteroids on salinity stress induced inhibition of seed germination and seedling growth of rice (Oryza sativa L.). Plant Growth Regul 33(2):151-153.

Arora N, Bhardwaj R, Sharma P, Arora HK (2008). Effects of 28-homobrassinolide on growth, lipid peroxidation and antioxidative enzyme activities in seedlings of Zea mays L. under salinity stress. Acta Physiol Plant 30(6):833-839.

Aydin Y, Talas-Ogras T, Ipekci-Altas Z, Gozukirmizi N (2006). Effects of brassinosteroid on cotton regeneration via somatic embryogenesis. Biologia 61(3): 289-293.

Bajguz A (2000). Effect of brassinosteroids on nucleic acids and protein content in cultured cells of Chlorella vulgaris. Plant Physiol Bioch 38(3):209-215.

Bajguz A, Hayat S (2009). Effects of brassinosteroids on the plant responses to environmental stresses. Plant Physiol Bioch 47(1):1-8.

Bhaduri AM, Fulekar MH (2012). Antioxidant enzyme responses of plants to heavy metal stress. Rev Environ Sci Biotechnol 11(1):55-69.

Bradford MM (1976). A rapid and sensitive method for the quantitation of microgram quantities of protein utilizing the principle of protein-dye binding. Anal Biochem 72(1-2):248-254.

Cakmak I, Marschner H (1992). Magnesium deficiency and high light intensity enhance activities of superoxide dismutase, ascorbate peroxidase and glutathione reductase in bean leaves. Plant Physiol 98(4):1222-1227.

Chen Z, Pottosin II, Cuin TA, Fuglsang AT, Tester M, Jha D, Zepeda-Jazo I, Zho M, Palmgren MG, Newman IA, Shabala S (2007). Root plasma membrane transporters controlling $\mathrm{K}^{+} / \mathrm{Na}^{+}$homeostasis in salt-stressed barley. Plant Physiol 145(4):1714-1725.

Cho YW, Park EH, Lim CJ (2000). Glutathione Stransferase activities of S-type and L-type thioltransferase from Arabidopsis thaliana. J Biochem Mol Biol 33(2):179183.

Choudhary SP, Oral HV, Bhardwaj R, Yu J-Q, Tran LSP (2012). Interactions of brassinosteroids and polyamines enhances copper stress tolerance in Raphanus sativus. J Exp Bot 63(15):5659-5675.

Clouse SD, Hall AF, Langford M, McMorris TC, Baker ME (1993). Physiological and molecular effects of brassinosteroids on Arabidopsis thaliana. J Plant Growth Regul 12:61-66.

Cuin TA, Shabala S (2007). Compatible solutes reduce ROS-induced potassium efflux in Arabidopsis roots. Plant Cell Environ 30(7):875-885.

Dash M, Panda SK (2001). Salt stress induced changes in growth and enzyme activities in germinating Phaseolus muingo seeds. Biol Plantarum 44(4):587-589. 
Demirkiran A, Marakli S, Temel A, Gozukirmizi N (2013). Genetic and epigenetic effects of salinity on in vitro growth of barley. Genet Mol Biol 36(4):566-570.

Dhaubhadel S, Chaudhary S, Dobinson KF, Krishna P (1999). Treatment with 24-epibrassinolide, a brassinosteroid, increases the basic thermotolerance of Brassica napus and tomato seedlings. Plant Mol Biol 40:333342.

El-Khallal SM, Hathout TA, Ashour AA, Kerrit AAA (2009). Brassinolide and salicylic acid induced growth, biochemical activities and productivity of maize plants grown under salt stress. Res J Agric Biol Sci 5(4):380-390.

Farooq M, Wahid A, Basra SMA Islam-ud-Din (2009). Improving water relations and gas exchange with brassinosteroids in rice under drought stress. J Agron Crop Sci 195(4):262-269.

Fariduddin Q, Khalil RRAE, MIR BA, Yusuf M, Ahmad A (2013). 24-Epibrassinolide regulates photosynthesis, antioxidant enzyme activities and proline content of Cucumis sativus under salt and/or copper stress. Environ Monit Assess 185(9):7845-7856.

Houimli SIM, Denden M, Mouhandes BD (2010). Effects of 24-epibrassinolide on growth, chlorophyll, electrolyte leakage and proline by pepper plants under $\mathrm{NaCl}$-stress. EurAsia J BioSci 4:96-104.

Howell WM, Keller III GE, Kirkpatrick JD, Jenkins RL, Hunsinger RN, Mclaughlin EW (2007). Effects of the plant steroidal hormone, 24-epibrassinolide, on the mitotic index and growth of onion (Allium cepa) root tips. Genet Mol Res 6(1):50-58.

$\mathrm{Hu}$ Y, Bao F, Li J (2000). Promotive effect of brassinosteroids on cell division involves a distinct $C y c D 3$ induction pathway in Arabidopsis. Plant J 24(5):693-701.

Kartal G, Temel A, Arican E, Gozukirmizi N (2009). Effects of brassinosteroids on barley root growth, antioxidant system and cell division. Plant Growth Regul 58(3):261-267.

Liu J, Gao H, Wang X, Zheng Q, Wang C, Wang X, Wang Q (2014). Effects of 24-epibrassinolide on plant growth, osmotic regulation and ion homeostasis of saltstressed canola. Plant Biol 16(2):440-450.

Miyazawa Y, Nakajima N, Abe T, Sakai A, Fujioka S, Kawano S, Kuroiwa T, Yashida S (2003). Activation of cell proliferation by brassinolide application in tobacco BY-2 cells: effects of brassinolide on cell multiplication, cell-cyclerelated gene expression, and organellar DNA contents. J Exp Bot 54(393):2669-2678.

Nunez M, Mazzafera P, Mazorra LM, Siqueira WJ, Zullo MAT (2003). Influence of a brassinosteroid analogue on antioxidant enzymes in rice grown in culture medium with $\mathrm{NaCl}$. Biol Plantarum 47(1):67-70.

Ozdemir F, Bor M, Demiral T, Turkan I (2004). Effects of 24-epibrassinolide on seed germination, seedling growth, lipid peroxidation, proline content and antioxidative system of rice (Oryza sativa L) under salinity stress. Plant Growth Regul 42:203-211.

Pan Y, Wu LJ, Yu ZL (2006). Effect of salt and drought stress on antioxidant enzymes activities and SOD isoenzymes of liquorice (Glycyrrhiza uralensis Fisch). Plant Growth Regul 49:157-165.
Parida AK, Das AB, Mittra B, Mohanty P (2004). Saltstress induced alterations in protein profile and protease activity in the Mangrove Bruguiera parviflora. $\mathrm{Z}$ Naturforsch C 59(5-6):408-414.

Rady MM (2011). Effect of 24-epibrassinolide on growth, yield, antioxidant system and cadmium content of bean (Phaseolus vulgaris L.) plants under salinity and cadmium stress. Scientia Horticulturae 129(2):232-237.

Saha P, Chatterjee P, Biswas AK (2010). NaCl pretreatment alleviates salt stress by enhancement of antioxidant defense system and osmolyte accumulation in mungbean (Vigna radiata L. Wilczek). Indian J Exp Biol 48(6):593-600.

Sairam RK, Srivastava GC (2002). Changes in antioxidant activity in sub-cellular fraction of tolerant and susceptible wheat genotypes in response to long term salt stress. Plant Sci 162(6):897-904.

Shabala $S$ (2009). Salinity and programmed cell death: unravelling mechanisms for ion specific signalling. J Exp Bot 60(3):709-712.

Shahbaz M, Ashraf M, Athar HR (2008). Does exogenous application of 24-epibrassinolide ameliorate salt induced growth inhibition in wheat (Triticum aestivum L.)? Plant Growth Regul 55(1):51-64.

Shahid MA, Pervez MA, Balal RM, Mattson NS, Rashid A, Ahmad R, Ayyub CM, Abbas T (2011). Brassinosteroid (24-epibrassinolide) enhances growth and alleviates the deleterious effects induced by salt stress in pea (Pisum sativum L.). Australian Journal of Crop Science 5(5):500510.

Sharma PC, Gupta PK (1982). Karyotypes in some pulse crops. Nucleus 25:181-185.

Sharma P, Bhardwaj R (2007). Effects of 24epibrassinolide on growth and metal uptake in Brassica juncea L. under copper metal stress. Acta Physiol Plant 29:259-263.

Sondhi N, Bhardwaj R, Kaur S, Kumar N, Singh B (2008). Isolation of 24- epibrassinolide from leaves of Aegle marmelos and evaluation of its antigenotoxicity employing Allium cepa chromosomal aberration assay. Plant Growth Regul 54(3):217-224.

Tabur S, Demir K (2009). Cytogenetic response of 24epibrassinolide on the root meristem cells of barley seeds under salinity. Plant Growth Regul 58(1):119-123.

Tabur S, Demir K (2010). Role of some growth regulators on cytogenetic activity of barley under salt stress. Plant Growth Regul 60:99-104.

Talaat NB, Shawky BT (2013). 24-Epibrassinolide alleviates salt-induced inhibition of productivity by increasing nutrients and compatible solutes accumulation and enhancing antioxidant system in wheat (Triticum aestivum L.). Acta Physiol Plant 35(3):729-740.

Tanou G, Molassiotis A, Diamantidis G (2009). Induction of reactive oxygen species and necrotic death-like destruction in strawberry leaves by salinity. Environ Exp Bot 65(2-3):270-281. 